\title{
Analysis of the ULF electromagnetic emission related to seismic activity, Teoloyucan geomagnetic station, 1998-2001
}

\author{
A. Kotsarenko ${ }^{1}$, R. Pérez Enríquez ${ }^{1}$, J. A. López Cruz-Abeyro ${ }^{1}$, S. Koshevaya ${ }^{2}$, V. Grimalsky ${ }^{3}$, and F. R. Zúñiga ${ }^{1}$ \\ ${ }^{1}$ Centro de Geociencias, Juriquilla, UNAM, Apdo Postal 1-742, Centro Queretaro, Querétaro, Mexico, C.P. 76001, Mexico \\ ${ }^{2}$ UAEM, Cuernavaca, Morelos, Mexico \\ ${ }^{3}$ INAOE, Tonantzintla, Puebla, Mexico
}

Received: 30 April 2004 - Revised: 27 October 2004 - Accepted: 28 October 2004 - Published: 1 November 2004

Part of Special Issue "Precursory phenomena, seismic hazard evaluation and seismo-tectonic electromagnetic effects"

\begin{abstract}
Results of ULF geomagnetic measurements at station Teoloyucan (Central Mexico, 99.11'35.735" W, $19.44^{\prime} 45.100^{\prime \prime} \mathrm{N}, 2280 \mathrm{~m}$ height) in relation to seismic activity in the period 1998-2001 and their analysis are presented. Variations of spectral densities for horizontal and vertical components, polarization densities and spectrograms of magnetic field, their derivatives are analyzed as a part of traditional analysis in this study. Values of spectral density were calculated for 6 fixed frequencies $f=1,3,10,30,100$ and $300 \mathrm{mHz}$. Fractal characteristics of spectra were analyzed in the conception of SOC (Self-Organized Criticality). 2 nighttime intervals, $0-3$ and $3-6 \mathrm{~h}$ by local time have been used to decrease the noise interference in row data. In order to exclude the intervals with a high geomagnetic activity from analysis we referred to $A p$ indices, calculated for corresponding time intervals. The contribution of seismic events to geomagnetic emission was estimated by seismic index $k_{s}=10^{0.75 M s} / 10 D$, where $M s$ is the amplitude of the earthquake and $D$ is the distance from its epicenter to the station.
\end{abstract}

\section{Introduction}

Different long-term observatories in Japan (Hayakawa, 1999), Russia (Molchanov, 2001, 2003), USA (Fraser-Smith, 1990, 1993), prove that the ULF EM band is very promising for monitoring of EM emission generated in the period preceding strong earthquakes and volcano eruptions. The ULF part of electromagnetic emission, generated by the earthquake, can be recorded at the Earth's surface by magnetometers without significant attenuation, if they are generated at typical earthquake nucleation depths $(\sim 10 \mathrm{~km})$. Higher frequencies would have smaller skin depths and therefore, greater attenuation before reaching the Earth's surface. In addition to that, the ULF geomagnetic equipment does not require complicated maintenance. Finally, the existing powerful methods of the data processing, such as spectral and polarization analysis (Hayakawa, et al., 2002), gradient metering and triangulation analysis (Ismaguilov et al., 2001, 2003), blind de-convolution technique (PCA analysis, Gotoh, Hayakawa et al., 2001, 2003; Kotsarenko, 2001), multifractal analysis (Smirnova et al., 2001) give a variety of application of mentioned methods of data processing and analysis of the results. The main aim of our study was to analyze the geomagnetic data observed at the station Teoloyucan during the period 1998-2001 and to find a statistical correlation between observed ULF EM emission and strong earthquakes occurred during that period of time.

\section{Experiment and methodology}

The geomagnetic data were collected at the station Teoloyucan $\left(99.11^{\prime} 35.735^{\prime \prime} \mathrm{W}, 19.44^{\prime} 45.100^{\prime \prime} \mathrm{N}, 2280 \mathrm{~m}\right.$ height) by 3 -coordinate fluxgate magnetometer designed at UCLA, operated at $1 \mathrm{~Hz}$ sampling rate frequency, equipped by a GPS system for data synchronization (Fig. 1).

Seismic data have been classified by 3 criteria: magnitude of earthquake $M s$, distance from epicenter of EQ $D$, and the seismic index (Molchanov et al., 2003) $k_{s}=10^{0.75 M s} / 10 D$, which was the main one (Fig. 2).

As well we referred to $A p$ indices, calculated for corresponding time intervals of seismic events in order to exclude from our analysis the events occurred during high geomagnetic activity Finally, there were only 5 earthquakes with $\boldsymbol{k}_{s}>10$ occurring under quiet geomagnetic conditions. Their characteristics, the map of the epicenters and the station location are shown at the Table 1 and in a Fig. 3.

The obtained results are distributed in three main blocks according to their applied technique. 


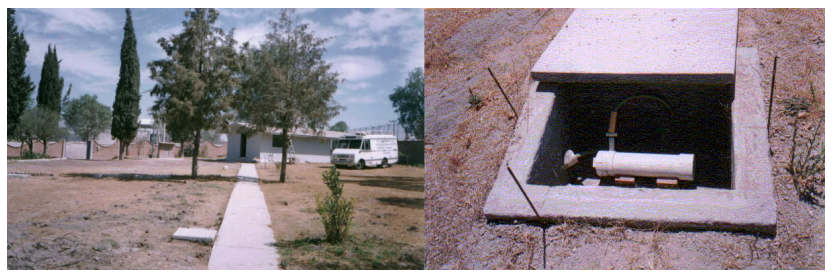

Fig. 1. Teoloyucan magnetic station and 3-component ULF magnetometer.

\subsection{Spectral and polarization analysis}

We have chosen 2 nighttime intervals, $0-3$ and $3-6 \mathrm{~h}$ by local time to decrease the noise interference in row data. Preliminary data processing includes filtering by running averaging with $2 \sigma$ screening and de-spike procedure in order to exclude spike-like noise (instrumental errors and human activity) and de-trended procedure to relieve local disturbances from the slow diurnal variation.

We calculated spectral values $S_{Z}$ and $S_{G}$ (where $G^{2}=H^{2}+D^{2}, G-$ total horizontal component), by PSD algorithm in 6 frequency sub-bands: $f=1,3,10,30,100$ and $300 \mathrm{mHz}$, with NFFT $=10800(3 \mathrm{~h})$; constructed polarization ratios $R=S_{Z} / S_{G}$, and their derivatives $R\left(\Delta f_{1}\right) / R\left(\Delta f_{2}\right)$; calculated 5400 daily values for $S_{Z}$ and $S_{G}$ and $R$ (with the same NFFT=10 800) for a construction of the annual spectrograms; and combined all the mentioned results with corresponding variation of $A p$ with a purpose to isolate EM emissions generated by seismic sources from global geomagnetic disturbances such as magnetic storms.

\subsection{The fractal analysis}

This procedure requires the graph of daily PSD $\mathrm{S}_{H, G}=S_{H, G}(f)$ to be presented with a logarithmic scale for both $\mathrm{x}$ - and $\mathrm{y}$-axes. Mentioning the frequency dependence as $S \sim f^{-\beta}$, we calculated the exponent $\beta$ by linear fit of the plotted dependence using least-squares. The shape of the PSD graphs was a quite different for the different 3-time intervals of data.

Some fractures and bends at definite frequencies appeared at most of noon and evening spectra, so the same 0-3 and 3-6 local time intervals have been used for this analysis.

2.3 The retrospective analysis of geomagnetic micropulsations in relation to seismic activity

We analyzed 5 seismic events, mentioned before, for a possible correlation with geomagnetic micropulsations, both continued and irregular ones, which occurred at the day of the earthquake, days before and after earthquake. Exception was the earthquake occurred on 30 September 1999, apparently none of the observed micropulsation has relation with geomagnetic activity and most probably they have been generated locally.
Table 1. The 5 strong and moderate earthquakes chosen for analysis.

\begin{tabular}{ccc}
\hline Date, GMT time & Magnitude, $M s$ & Depth, km \\
\hline 15 June 1999, 20:42 & 7.0 & 69 \\
30 September 1999, 16:31 & 7.5 & 16 \\
9 August 2000, 11:41 & 6.5 & 16 \\
19 May 2001, 23:21 & 6.5 & 20 \\
7 October 2001, 21:39 & 6.1 & 10 \\
\hline
\end{tabular}

We have used Matlab-based software () Hannes Schwarzl, UCLA University) to filtrate data in corresponding frequency sub-band, related to proper geomagnetic pulsations, process and analyze them using powerful a interface.

As well we referred to the data of other geomagnetic stations in order to verify the character of the observed effects, global or local ones.

\section{Description analysis of the obtained results}

The analysis of the temporal dynamics of spectral densities $S_{Z, G}$, polarization ratios $R=S_{Z} / S_{G}$, their derivatives and annual spectrograms reveals following features: noticeable increase for the values of most of the mentioned characteristics in periods about 14-30 days before 3 of 5 earthquakes: moderate increase expressed at lower frequencies for the earthquake occurred on 15 June 1999, and high, multispike-like increase at all frequency sub-bands for earthquakes occurred on 30 September 1999 and 19 May 2001 (Fig. 4), especially clearly seen in the polarization ratio variations. Almost all the mentioned changes in spectra and polarization took place during quiet local geomagnetic activity ( $A p$ low). These events have duration from 1 to 2 weeks, corresponding change of values are: up to tens nano Tesla in absolute values, up to tens of $\mathrm{nT}^{2} / \mathrm{Hz}$ for spectral values and up to 10 time in polarization ratio. Such a feature can be interpreted as a possible ULF geomagnetic emission generated in the earthquake preparation site. There was no noticeable event observed for the other 2 earthquakes. All other changes in spectral variation can be explained by moderate and high magnetospheric activity.

Variations of fractal indices for the vertical $(\mathrm{Z})$ and total horizontal $(\mathrm{G})$ components and their ratio $(\mathrm{Z} / \mathrm{G})$, calculated for 3 years, reveal only 1 significant change in their dynamics, related to earthquake occurred on 19 May 2001. Noticeable noise-like behavior with slight increase in Z-component and some drops in G-component occurred in about 1 month before that earthquake with approximate duration about 20 days (Fig. 5).

The example of observed micropulsations related to the earthquake occurred on 15 June 1999 at 20:42 GMT is presented at Fig. 6. The complete description of the observed events one can see in the Table 2. 
Table 2. The geomagnetic activity (Pc1-5, Pi1,2) during 5 strong and moderate earthquakes chosen for analysis.

\begin{tabular}{|c|c|c|c|c|c|}
\hline DATE & 15 June 1999 & 30 Sept. 1999 & 9 Aug. 2000 & 19 May 2001 & 7 Oct. 2001 \\
\hline DST & $\begin{array}{l}\text { Magnetic silence } \\
\text { during all the } \\
\text { June }\end{array}$ & $\begin{array}{l}\text { Magnetic storm } 7 \\
\text { days before the } \\
E Q \text {, low activity at } \\
\text { the day before the } \\
E Q\end{array}$ & $\begin{array}{l}\text { Low activity the } \\
\text { day before } E Q \text { and } \\
4 \mathrm{~h} \text { before the } E Q\end{array}$ & $\begin{array}{l}\text { Low activity during } \\
\text { the day of the } E Q \\
\text { and about } 2 \text { days } \\
\text { before the } E Q\end{array}$ & $\begin{array}{l}\text { Low activity during } \\
\text { the October }\end{array}$ \\
\hline $\mathrm{AE}$ & $\begin{array}{l}\text { Quiet } \\
\text { magnetically } \\
\text { during the } E Q \text {, } \\
\text { hours before and } \\
\text { after the } E Q\end{array}$ & $\begin{array}{l}\text { Low activity during } \\
\text { the day of the } E Q \\
\text { at the auroral zone }\end{array}$ & $\begin{array}{l}\text { Quiet magnetically } \\
\text { during the } E Q \text {, } \\
\text { several hours } \\
\text { before and hours } \\
\text { after the EQ }\end{array}$ & $\begin{array}{l}\text { Low activity during } \\
\text { the day of } E Q \text { and } \\
\text { some hours after } \\
\text { the EQ }\end{array}$ & $\begin{array}{l}\text { Quiet magnetically } \\
\text { during the } E Q \text {, } \\
\text { hours before and } \\
\text { after the } E Q\end{array}$ \\
\hline $\mathrm{K}_{\mathrm{P}}$ & $\begin{array}{l}\text { Quiet period } 5 \\
\text { days before and } \\
10 \text { days after } E Q\end{array}$ & $\begin{array}{l}\text { Moderate magnetic } \\
\text { activity at the day } \\
\text { of the } E Q \text { and } \\
\text { preceding days }\end{array}$ & $\begin{array}{l}\text { Low activity at the } \\
\text { day of the EQ and } \\
3 \text { days before }\end{array}$ & $\begin{array}{l}\text { Low activity during } \\
\text { the day of } E Q \text { and } \\
\text { some days after } \\
\text { the } E Q\end{array}$ & $\begin{array}{l}\text { Low activity at the } \\
\text { day of the EQ, } 3 \\
\text { days before and } 4 \\
\text { days after }\end{array}$ \\
\hline Pc1-2 & $\begin{array}{l}\text { Activity of } B_{Z} \text { the } \\
\text { day before } E Q, 4 \\
\mathrm{~h} \text { before, and } 2 \mathrm{~h} \\
\text { after the } E Q\end{array}$ & No activity & $\begin{array}{l}\text { Low activity of } B_{Z} 7 \\
\text { h. before the } E Q \\
\text { and the day before } \\
\text { at } 09: 00\end{array}$ & $\begin{array}{l}\text { No activity before } \\
\text { the } E Q \text { and low } \\
\text { activity } 1 \mathrm{~h} \text { after } \\
\text { the } E Q \text { in } \\
\text { component } B_{z}\end{array}$ & $\begin{array}{l}\text { Activity } 2 \mathrm{~h} \text { before } \\
\text { the } E Q \text { in } B_{H} \text { and } \\
B_{z} \text {, and } 4 \mathrm{~h} \text { after }\end{array}$ \\
\hline Pc3 & $\begin{array}{l}\text { Activity of } B_{Z} \text { the } \\
\text { day preceding } E Q \\
4 \mathrm{~h} \text { and } 2 \mathrm{~h} \text { after } \\
\text { the EQ. }\end{array}$ & No activity & $\begin{array}{l}\text { Low activity of } B_{Z} 7 \\
h \text { before the EQ } \\
\text { and the day before } \\
\text { at } 09: 00\end{array}$ & $\begin{array}{l}\text { No activity before } \\
\text { the } E Q \text { and low } \\
\text { activity } 1 \mathrm{~h} \text { after } \\
\text { the } E Q \text { in } \\
\text { component } B_{z}\end{array}$ & $\begin{array}{l}\text { Activity } 2 \mathrm{~h} \text {. before } \\
\text { the } E Q \text { in } B_{H} \text { y } B_{Z}\end{array}$ \\
\hline Pc4 & $\begin{array}{l}\text { Activity of } B_{Z} \text { at } \\
\text { the previous day } \\
\text { at } 4 \mathrm{~h} \text {, the day of } \\
\text { the } E Q \text { at } 0 \mathrm{~h} \text { and } \\
\text { at } 12 \mathrm{~h}, 2 \mathrm{~h} \text { after } \\
\text { the } \mathrm{EQ}\end{array}$ & $\begin{array}{l}\text { Activity of } 3 \\
\text { components the } \\
\text { day before at } 9 \mathrm{~h} \\
\text { and } 6 \mathrm{~h} \text { before the } \\
\mathrm{EQ}\end{array}$ & $\begin{array}{l}\text { Activity of } B_{Z} \text { the } \\
\text { day before at } 9 \mathrm{~h} \\
\text { and } 2 \mathrm{~h} \text { before the } \\
\mathrm{EQ}\end{array}$ & $\begin{array}{l}\text { No activity at days } \\
\text { of EQ neither } \\
\text { before and after } \\
\text { EQ }\end{array}$ & $\begin{array}{l}\text { Activity the day } \\
\text { before the EQ in } 3 \\
\text { components, } \\
\text { several minutes } \\
\text { after the } E Q \text { in } B_{Z} \text {, } \\
\text { and } 6 \text { h after the } \\
\text { EQ }\end{array}$ \\
\hline Pc5 & $\begin{array}{l}\text { Activity of } 3 \\
\text { components at } \\
\text { the previous day } \\
\text { at } 4 \mathrm{~h} \text { and the day } \\
\text { of the } E Q \text { at } 12 \mathrm{~h} \text {. } \\
3 \text { components } \\
\text { and } 2 \mathrm{~h} \text { after } \\
\text { activity of } B_{Z}\end{array}$ & $\begin{array}{l}\text { Activity of } 3 \\
\text { components the } \\
\text { day before at } 9 \mathrm{~h} \text {, } \\
\text { high activity during } \\
\text { the day of the EQ, } \\
\text { activity of } B_{Z} \text { the } \\
\text { day after EQ }\end{array}$ & $\begin{array}{l}\text { Activity of } B_{Z} \text { the } \\
\text { day before at } 9 \mathrm{~h}, 7 \\
\mathrm{~h} \text { before the } E Q \\
\text { and } 1 \mathrm{~h} \text { after }\end{array}$ & $\begin{array}{l}\text { Activity } 14 \mathrm{~h} \text {. } \\
\text { Before the } E Q-3 \\
\text { components, } 8 \mathrm{~h} \text {. } \\
\text { before - in } B_{z} \text {, and } \\
1 \text { day after }- \text { in } B_{z}\end{array}$ & $\begin{array}{l}\text { Activity the day } \\
\text { before the EQ at } 4 \\
\mathrm{~h} \text { and } 12 \mathrm{~h} \text { in } 3 \\
\text { components, } 11 \mathrm{~h} \\
\text { after the } E Q \text { in } B_{z} \text {, } \\
6 \mathrm{~h} \text { after the } E Q \text { in } \\
\mathrm{B}_{\mathrm{z}}\end{array}$ \\
\hline $\mathrm{Pi} 1$ & $\begin{array}{l}\text { Activity of } B_{z} \text { at } \\
\text { the previous day } \\
\text { at } 4 \mathrm{~h} \text { and } 2 \mathrm{~h} \\
\text { after the EQ }\end{array}$ & No activity & $\begin{array}{l}\text { Activity of } B_{Z} \text { the } \\
\text { day before at } 9 \mathrm{~h}, 7 \\
\mathrm{~h} \text { before the } E Q\end{array}$ & $\begin{array}{l}\text { No activity at days } \\
\text { of } E Q \text { neither } \\
\text { before and after } \\
E Q\end{array}$ & $\begin{array}{l}\text { Activity at } 2 \mathrm{~h} \\
\text { before the } E Q \text { and } \\
4 \mathrm{~h} \text { after in } B_{H} \text { and } \\
B_{Z}\end{array}$ \\
\hline $\mathrm{Pi} 2$ & $\begin{array}{l}\text { Activity of } B_{Z} \text { at } \\
\text { the previous day } \\
\text { at } 4 \mathrm{~h} \text {, the day of } \\
\text { the EQ at } 0 \mathrm{~h} \text { and } \\
12 \mathrm{~h}, 2 \mathrm{~h} \text { after the } \\
\mathrm{EQ}\end{array}$ & $\begin{array}{l}\text { Low activity of } 3 \\
\text { components day } \\
\text { before and } 6 \mathrm{~h} \\
\text { before the } E Q \text { and } \\
\text { the next day after } \\
\text { the EQ }\end{array}$ & $\begin{array}{l}\text { Activity of } B_{Z} \text { the } \\
\text { day before at } 9 \mathrm{~h}, 7 \\
\mathrm{~h} \text { before the } E Q\end{array}$ & No clear activity & $\begin{array}{l}\text { Activity during the } \\
E Q \text { and several } \\
\text { minutes after }\end{array}$ \\
\hline Correlation with $\mathrm{EQ}$ & Positive & Low Positive & Positive & Slightly Positive & Positive \\
\hline
\end{tabular}
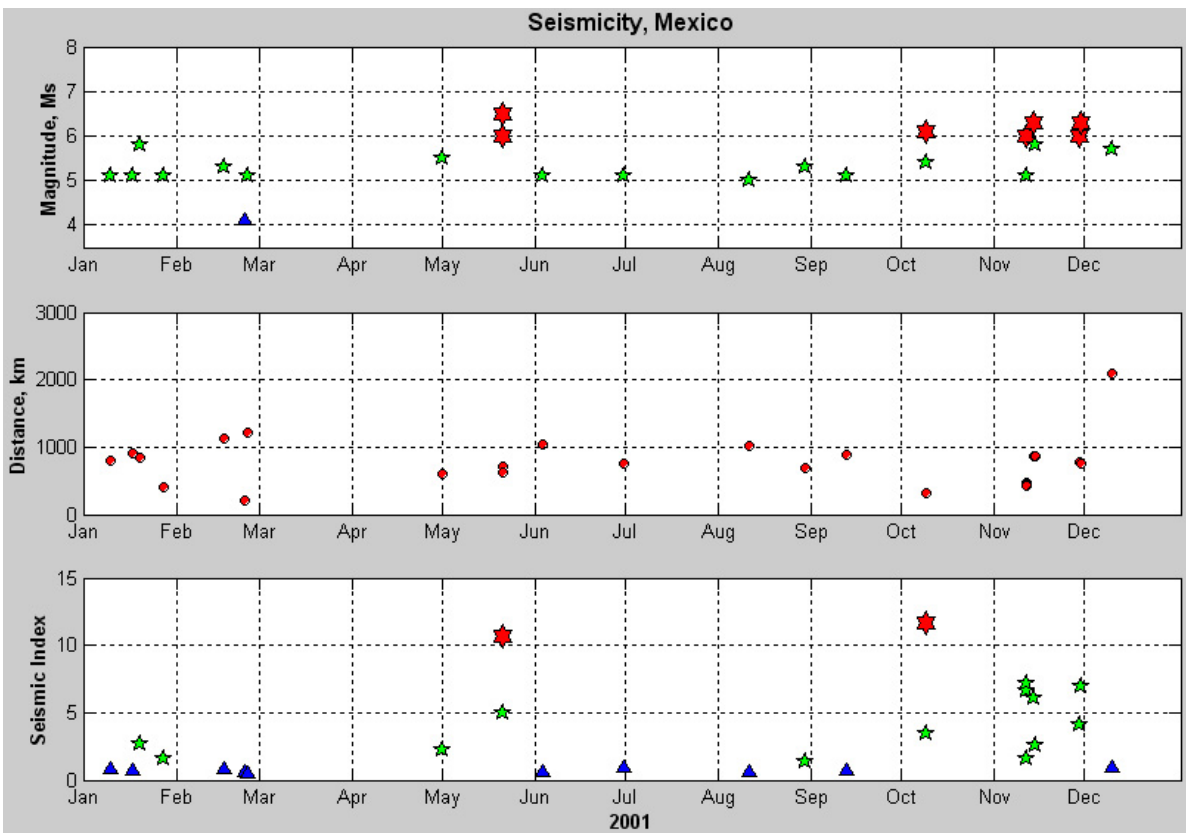

Fig. 2. Seismicity in Mexico in 2001. Ms are magnitudes of the EQs; distances from the epicenter $D$ and seismic index $k_{S}$ are calculated for Teoloyucan geomagnetic station. 


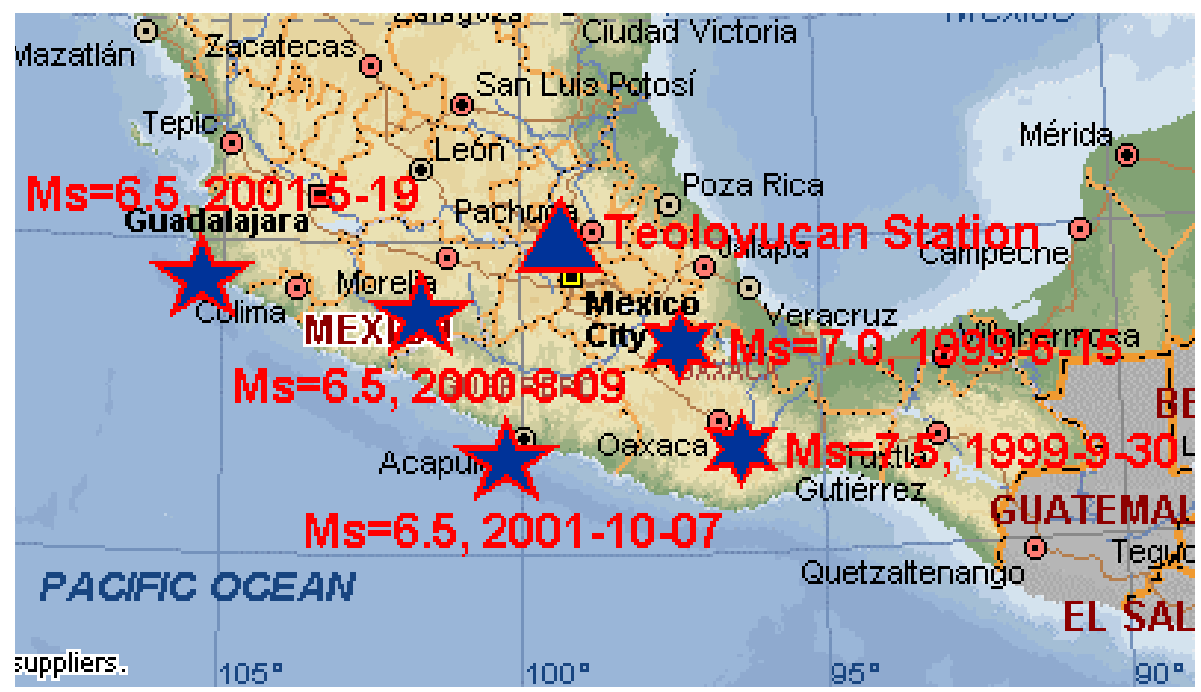

Fig. 3. Map of epicenters (stars) of earthquakes discussed and Teoloyucan magnetic station (triangle).

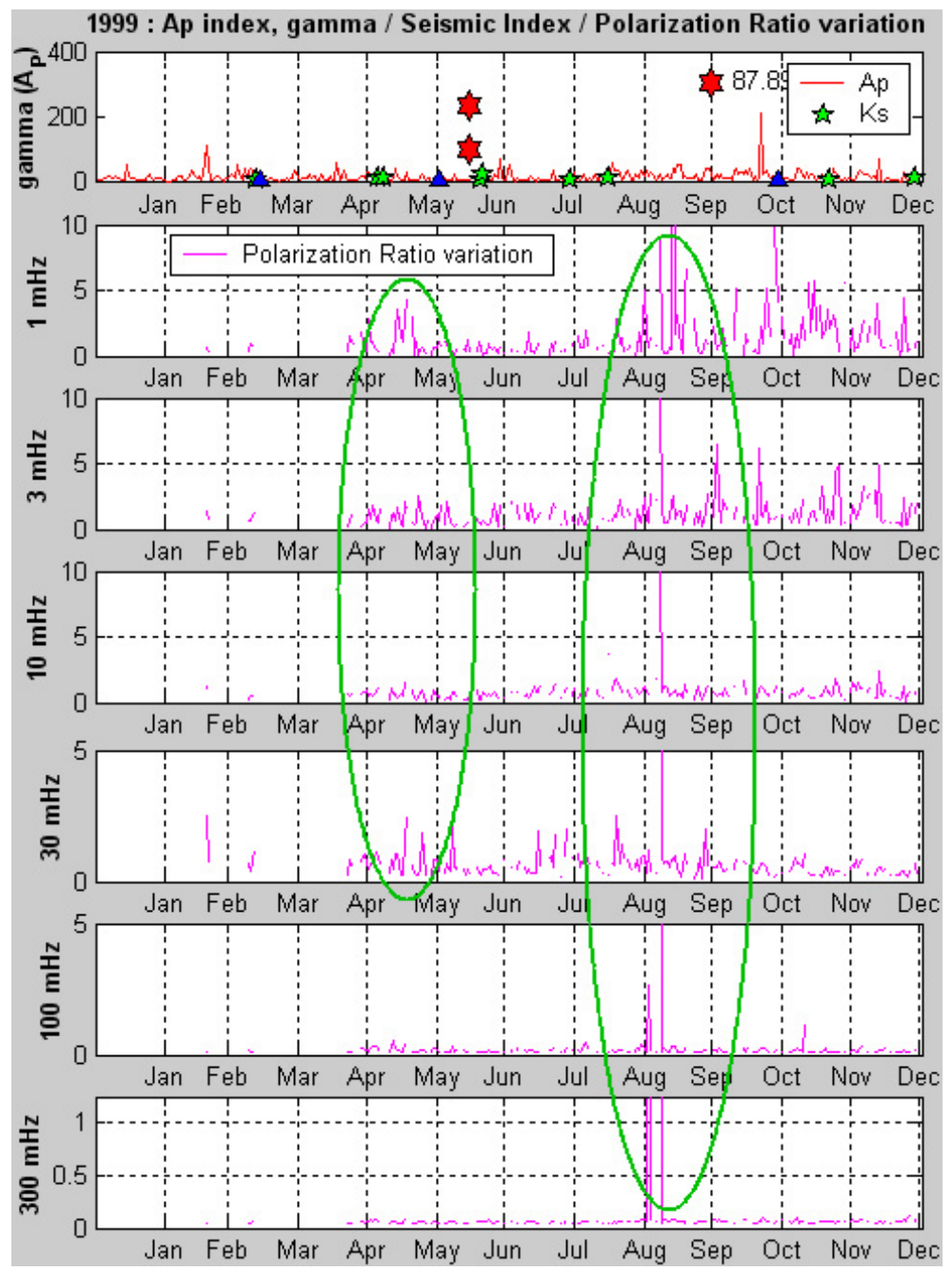

Fig. 4. Temporal variation of polarization ratio calculated for 6 frequency sub-bands, upper panel - seismic activity $\left(k_{S}\right.$ index $)$ and geomagnetic activity $\left(A_{P}\right.$ index $)$ dynamics, 1999. 

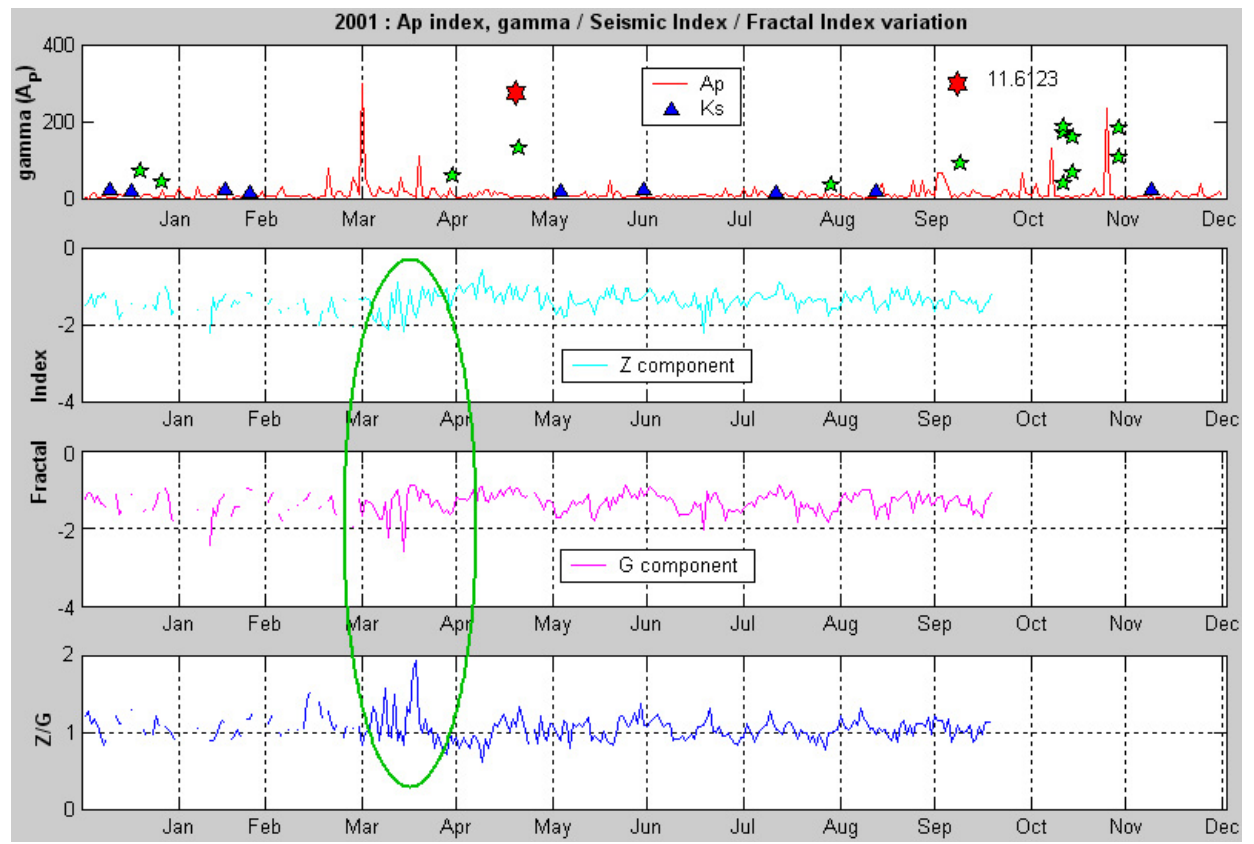

Fig. 5. Temporal variation of fractal index, upper panel - seismic activity $\left(k_{S}\right.$ index $)$ and geomagnetic activity $\left(A_{P}\right.$ index $)$ dynamics, 2001.

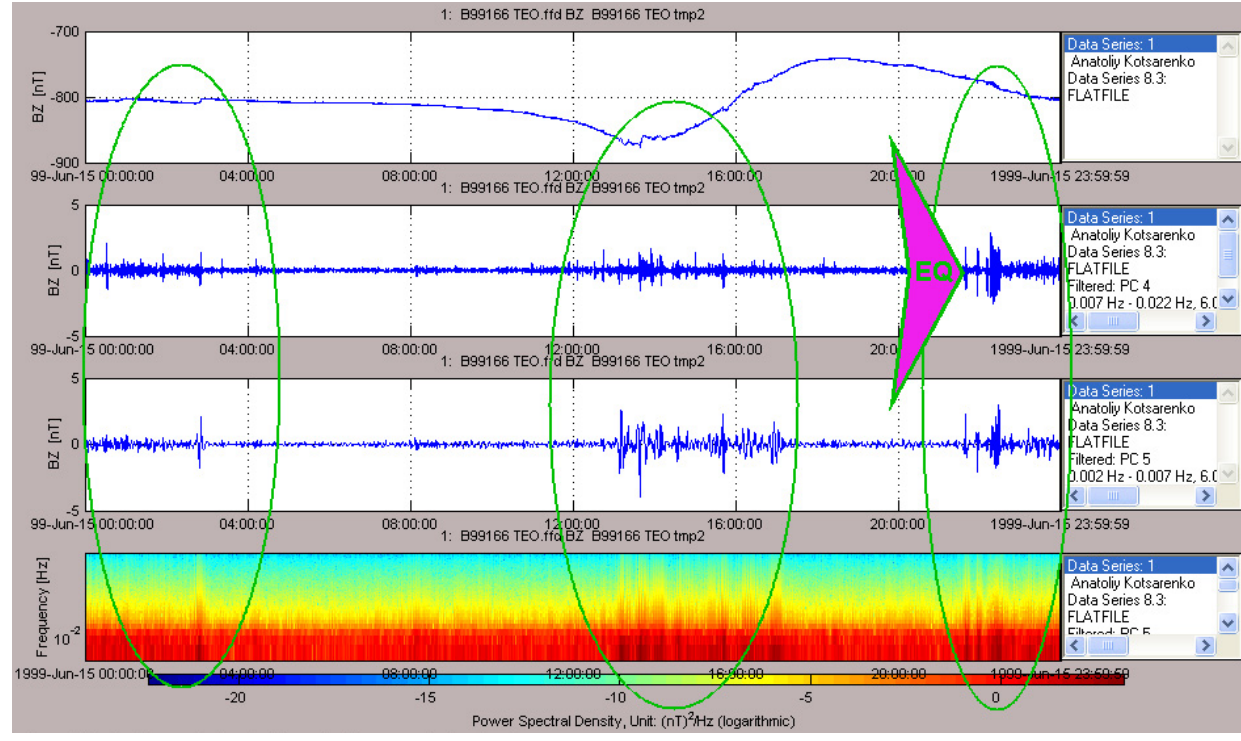

Fig. 6. Micropulsations, observed on 15 June 1999 in component $Z$. Upper panel $-B_{Z}$ time series, second panel - PC4 sub-band, third panel - PC5 sub-band, lower panel - daily spectrogram for PC5. The earthquake time is marked with a violet mark.

Generally all the observed evens can be classified in 3 blocks due to their occurrence time: pre-seismic (before the earthquake), co-seismic (at the exact time of the earthquake and during it) and post-seismic events observed at different sub-bands. Most of events, classified in the table, have no relation neither with global nor with local geomagnetic activity, which was proven by checking with $D S T, K_{P}$ and $A E$ geomagnetic indices and by comparing obtained results with the results based on the data of another geomagnetic stations.

Moreover, observed micropulsations normally do not occur at all during the days with absent or low geomagnetic activity. For these reasons we can testify the probable relation of the observed events with the effects of the preparation of the earthquakes.

\section{Conclusions}

In this paper we have studied geomagnetic data performing analysis in 3 different conceptions. The traditional one, such as construction of spectral long time series $\left(S_{Z} S_{G}\right.$, $R=S_{Z} / S_{G}$, their derivatives and spectrograms), calculated 
for different ULF sub-bands; Fractal analysis and multianalysis of geomagnetic micropulsation data corresponding to 5 strong and moderate earthquakes with magnitudes greater than 6.0, that occurred in Mexico during 1999-2001.

We found the following:

1. In the case of 3 of the mentioned events studied within the concept of traditional analysis, most characteristics show noticeable increase, taking place from 14 to 30 days in almost all frequencies, mainly at the lower ones.

2. For the fractal analysis, there was only one significant change with 20 days duration, that occurred in about one month prior to the corresponding earthquake.

3. Some micropulsations not associated to magnetospheric activity were present before, during and after some major earthquakes, some of them shown in all three components of the magnetic field.

We are aware that these results are still with the possibility of improvement with more extended network observations and therefore, with the possibility of applying other advanced techniques.

Edited by: P. F. Biagi

Reviewed by: one referee

\section{References}

Fraser-Smith, A. C., Bernardy, A., McGill, P. R., Ladd, M. E., Helliwell, R. A., and Villard Jr., O. G.: Low frequency magnetic field measurements near the epicenter of the Ms 7.1 Loma Prieta earthquake, Geophys. Res. Lett., 17, 1465-1468, 1990.

Fraser-Smith, A. C.: Analysis of low-frequency electromagnetic field measurements near the epicenter, Loma Prieta, California, Earthquake of 17 October 1989, Preseismic observations, U.S. Geol. Survey Prof. Paper 1550-C, C 17-C251, 1993.

Gotoh K., Hayakawa, M., and Smirnova, N.: Fractal analysis of the ULF geomagnetic data obtained at Izu Peninsula, Japan in relation to the nearby earthquake swarm of June-August 2000, Nat. Haz. Earth Syst. Sci., 3, 229-236, 2003,

SRef-ID: 1684-9981/nhess/2003-3-229.
Hattori, K., Gotoh, K., Hayakawa, M. et al.: ULF geomagnetic anomaly associated with earthquakes around Izu islands, Japan 2000, Proceedings of URSI General Assembly, 2002.

Hayakawa, M., Ito, T., and Smirnova, N.: Fractal analysis of ULF geomagnetic data associated with the Guam earthquake on $8 \mathrm{Au}-$ gust 1993, Geophys. Res. Lett., 26, 2797-2800, 1999.

Ismaguilov, V., Kopytenko, Yu., Hattori, K., Voronov, P., Molchanov, O., and Hayakawa, M.: ULF magnetic emissions connected with under sea bottom earthquakes. Nat. Haz. Earth Syst. Sci., 1, 23-31, 2001,

SRef-ID: 1684-9981/nhess/2001-1-23.

Ismaguilov, V., Kopytenko, Yu., Hattori, K., and Hayakawa, M.: Variations of phase velocity and gradient values of ULF geomagnetic disturbances connected with the Izu strong earthquakes, Nat. Haz. Earth Syst. Sci., 3, 211-215, 2003,

SRef-ID: 1684-9981/nhess/2003-3-211.

Kotsarenko, A., Hayakawa, M., Molchanov, O., Koshova, S., and Grimalsky, V.: Results of the ULF magnetic field measurements during the seismic period at Izu peninsula, Japan, Puerto Vallarta, Jal., Mexico, Unión Geofísica Mexicana, 21 N 3, 170, 2001.

Kotsarenko A., Molchanov, O., Hayakawa, M., Koshevaya, S., Grimalsky, V., Pérez Enríquez, R., and López Cruz-Abeyro, J. A.: Investigation of ULF magnetic anomaly during Izu earthquake swarm and Miyakejima volcano eruption at summer 2000, Japan, the IEEE 2003 International Symposium on Electromagnetic Compatibility (EMC), Istanbul, Turkey, MO-A-P1, N 11, 2003.

Molchanov, O., Schekotov, A., Fedorov, E., Belyaev, G., and Gordeev, E.: Preseismic ULF electromagnetic effect from observation at Kamchatka, Nat. Haz. Earth Syst. Sci., 3, 203-209, 2003,

SRef-ID: 1684-9981/nhess/2003-3-203.

Molchanov, O. A., Schekotov, A. Yu., Fedorov, E., and Hayakawa, M.: Ionospheric Alfvén resonance at middle latitudes: results of observations at Kamchatka, Phys. Chem. Earth, 29, 649-655, 2004.

Smirnova, N., Hayakawa, M., Gotoh, K., and Volobuev, D.: Scaling characteristics of ULF geomagnetic fields at the Guam seismoactive area and their dynamics in relation to the earthquake, Nat. Haz. Earth Syst. Sci., 1, 119-126, 2001,

SRef-ID: 1684-9981/nhess/2001-1-119. 